\title{
COMPARISON OF TWO FORMS OF ERLANGIAN DISTRIBUTION LAW IN QUEUING THEORY
}

Tarasov V. N. - Dr. Sc., Professor, Head of Department of Software and Management in Technical Systems of Volga State University of Telecommunications and Informatics, Samara, Russian Federation.

\section{ABSTRACT}

Context. For modeling various data transmission systems, queuing systems $\mathrm{G} / \mathrm{G} / 1$ are in demand, this is especially important because there is no final solution for them in the general case. The problem of the derivation in closed form of the solution for the average waiting time in the queue for ordinary system with erlangian input distributions of the second order and for the same system with shifted to the right distributions is considered.

Objective. Obtaining a solution for the main system characteristic - the average waiting time for queue requirements for three types of queuing systems of type $\mathrm{G} / \mathrm{G} / 1$ with usual and shifted erlangian input distributions.

Method. To solve this problem, we used the classical method of spectral decomposition of the solution of Lindley integral equation, which allows one to obtain a solution for average the waiting time for systems under consideration in a closed form. For the practical application of the results obtained, the well-known method of moments of the theory of probability was used.

Results. For the first time, spectral expansions of the solution of the Lindley integral equation for systems with ordinary and shifted Erlang distributions are obtained, with the help of which the calculation formulas for the average waiting time in the queue for the above systems in closed form are derived.

Conclusions. The difference between the usual and normalized distribution is that the normalized distribution has a mathematical expectation independent of the order of the distribution $k$, therefore, the normalized and normal Erlang distributions differ in numerical characteristics. The introduction of the time shift parameter in the laws of input flow distribution and service time for the systems under consideration turns them into systems with a delay with a shorter waiting time. This is because the time shift operation reduces the coefficient of variation in the intervals between the receipts of the requirements and their service time, and as is known from queuing theory, the average wait time of requirements is related to these coefficients of variation by a quadratic dependence. The system with usual erlangian input distributions of the second order is applicable only at a certain point value of the coefficients of variation of the intervals between the receipts of the requirements and their service time. The same system with shifted distributions allows us to operate with interval values of coefficients of variations, which expands the scope of these systems. This approach allows us to calculate the average delay for these systems in mathematical packages for a wide range of traffic parameters.

KEYWORDS: Ordinary and normalized Erlangian distribution laws, Lindley integral equation, spectral decomposition method, Laplace transform.

\begin{abstract}
ABBREVIATIONS
LIE is a Lindley integral equation;

QS is a queuing system;

PDF is a probability distribution function.
\end{abstract}

\section{NOMENCLATURE}

$f_{\lambda}(t)$ is a density function of the distribution of time between arrivals;

$F_{\lambda}^{*}(s)$ is a Laplace transform of the function $f_{\lambda}(t)$;

$f_{\mu}(t)$ is a density function of the distribution of service time;

$F_{\mu}^{*}(s)$ is a Laplace transform of the function $f_{\mu}(t)$;

$c_{\lambda}$ the coefficient of variation of time between arrivals;

$c_{\mu}$ the coefficient of variation of service time;

$\mathrm{E}_{2}$ is an erlangian distribution of the second order;

$\mathrm{E}_{2}^{-}$is a shifted erlangian distribution of the second order;

$\mathrm{G}$ is an arbitrary distribution law;

$\bar{W}$ is an average delay in the queue;

$W^{*}(s)$ is a Laplace transform of delay density function; $\lambda$ is a parameter of the erlangian distribution law of the input flow;

$\mu$ is a parameter of the erlangian distribution law of service time;

$\rho$ is a system load factor;

$\bar{\tau}_{\lambda}$ is an average time between arrivals;

$\bar{\tau}_{\lambda}^{2}$ is a second initial moment of time between arrivals;

$\bar{\tau}_{\mu}$ is an average service time;

$\overline{\tau_{\mu}^{2}}$ is a second initial moment of service time;

$\Phi_{+}(s)$ is a Laplace transform of the PDF of waiting time;

$\psi_{+}(s)$ is a first component of spectral decomposition;

$\psi_{-}(s)$ is a second component of spectral decomposition;

$\chi(t)$ is a characteristic function of a random variable.

\section{INTRODUCTION}

This article is devoted to the analysis of the $\mathrm{E}_{2} / \mathrm{E}_{2} / 1$ QS with ordinary Erlang distributions, for which no results were found in the public domain on the average 
delay of requests in the queue, which is the main characteristic for any QS. According to this characteristic, for example, packet delays in packet-switched networks are estimated when they are modeled using QS.

We also investigated the above system with timeshifted input Erlang distributions in order to obtain a solution for the average delay. A shift of the distribution law to the right from the zero point transforms the usual system $E_{2} / E_{2} / 1$ into a system of the $G / G / 1$ type. In queuing theory, studies of $\mathrm{G} / \mathrm{G} / 1$ systems are especially relevant due to the fact that there is no solution in the final form for the general case. Therefore, such systems are considered under different distribution laws.

In the study of $\mathrm{G} / \mathrm{G} / 1$ systems, an important role is played by the method of spectral decomposition of the solution of the Lindley integral equation, and most of the results in the theory of queuing were obtained using this method. In the previous works of the authors, it is clearly shown that in systems formed by shifted distribution laws, with the same load factor as compared with conventional systems, the average delay becomes less.

This is achieved because the coefficients of variation of the arrival $c_{\lambda}$ and service times $c_{\mu}$ for shifted distribution laws become smaller when entering the shift parameter $t_{0}>0$

The object of study is the main characteristic - the average waiting time of requirements in the queue of the queueing systems type $\mathrm{G} / \mathrm{G} / 1$.

The subject of study is the average waiting time of requirements in the queue of the $\mathrm{QS} \mathrm{E}_{2} / \mathrm{E}_{2} / 1$ and in the same system, but with shifted input distributions.

The purpose of the work is obtaining a solution for the average delay of requirements in the queue in closed form for these systems.

\section{PROBLEM STATEMENT}

The paper poses the problem of finding a solution for the waiting time of requests in the queue in the ordinary system $E_{2} / E_{2} / 1$ formed by Erlang distributions, as a special case of the gamma distribution and in the system formed by shifted Erlang distributions. This task also involves identifying the differences between the usual and normalized Erlang distributions. To solve the problem, we used the apparatus of spectral decomposition of the Lindley integral equation.

Let us briefly recall the main content of the method of spectral decomposition of the LIE solution based on the classics of the queuing theory [1]. The solution of the LIE by the spectral decomposition method consists in finding the representation for the expression $F_{\lambda}^{*}(-s) \cdot F_{\mu}^{*}(s)-1$ in the form of a fractional rational function, i.e. as a product of two factors, which would give a rational function of $s$.

When using the method of spectral decomposition of an LIE solution to determine the average waiting time, we will follow the approach and symbolism of the author of the classical queuing theory [1]. To solve the problem, it is necessary to find the law of waiting time distribution in (C) Tarasov V. N., 2021 DOI $10.15588 / 1607-3274-2021-3-5$ the system through the spectral decomposition of the form: $F_{\lambda}^{*}(-s) F_{\mu}^{*}(s)-1=\psi_{+}(s) / \psi_{-}(s)$, where $\psi_{+}(s)$ and $\psi_{-}(s)$ are some fractional rational functions of $\mathrm{s}$ that can be factorized. Functions $\psi_{+}(s)$ and $\psi_{-}(s)$ must satisfy special conditions according to [1], which can be found in the previous works of the authors [2-6].

Thus, to solve the problem, it is necessary to construct spectral expansions of the form $F_{\lambda}^{*}(-s) F_{\mu}^{*}(s)-1=\psi_{+}(s) / \psi_{-}(s)$ for the systems under consideration, considering the conditions specified above in each case.

\section{REVIEW OF THE LITERATURE}

The method of spectral decomposition of the solution of the Lindley integral equation used in this work was first presented in detail in the classics of queuing theory [1], and was subsequently applied in many works, including $[8,9,13]$. A different approach to solving Lindley's equation has been used in Russian language literature. That work used factorization instead of the term "spectral decomposition" and instead of the functions $\psi_{+}(s)$ and $\psi_{-}(s)$ it used factorization components $\omega_{+}(z, t)$ and $\omega_{-}(z, t)$ of the function $1-z \cdot \chi(t)$, where $\chi(t)$ is the characteristic function of a random variable $\xi$ with an arbitrary distribution function $C(t)$, and $z$ is any number from the interval $(-1,1)$. This approach for obtaining results for systems under consideration is less convenient than the approach described and illustrated with numerous examples in [1].

The method of spectral decomposition of the LIE solution was also used to study systems with different input distributions in [2-6]. At the same time, the scientific literature, including web resources, the author failed to find the results on the waiting time for the QS with Erlang distributions, as a special case of the gamma distribution. Among foreign publications, it is worth highlighting $[10,11]$, in which it is proposed to consider the queue of requests to Internet resources as queues with a time lag.

The results of works [2-6] together with [1] allowed developing the theory of the method of spectral decomposition of the LIE solution into the usual secondorder Erlang distribution shifted to the right from the zero point.

Approximation methods with respect to distribution laws are described in detail in [9, 13, 14], and similar studies in queuing theory have recently been carried out in [15-24].

\section{MATERIALS AND METHODS}

As you know, the two-parameter gamma distribution is given by the density function of the form 


$$
f(t)= \begin{cases}\frac{\beta^{-\alpha} t^{\alpha-1} e^{-t / \beta}}{\Gamma(\alpha)}, & t \geq 0, \\ 0, & t<0,\end{cases}
$$

where $\Gamma(\alpha)$ is a gamma function equal $\Gamma(z)=\int_{0}^{\infty} t^{z-1} e^{-t} d t$

for any real number $z>0, \alpha>0, \beta>0$. Next, we need the numerical characteristics of the gamma distribution: the mean value of the interval $\bar{\tau}=\alpha \beta$ and the coefficient of variation $c=1 / \sqrt{\alpha}$. To apply the spectral decomposition method, we find the Laplace transform of the gamma distribution

$$
\begin{aligned}
& F^{*}(s)=\frac{\beta^{-\alpha}}{\Gamma(\alpha)} \int_{0}^{+\infty} e^{-s t} t^{\alpha-1} e^{-t / \beta} d t=\frac{\beta^{-\alpha}}{\Gamma(\alpha)} \int_{0}^{+\infty} t^{\alpha-1} e^{-(s+1 / \beta) t} d t= \\
& =\left|\begin{array}{l}
(s+1 / \beta) t=x \\
t=\frac{\beta}{\beta s+1} x \\
d t=\frac{\beta}{\beta s+1} d x
\end{array}\right|=\frac{\beta^{-\alpha}}{\Gamma(\alpha)}\left(\frac{\beta}{\beta s+1}\right)^{\alpha} \int_{0}^{+\infty} x^{\alpha-1} e^{-x} d x= \\
& =\frac{\beta^{-\alpha}}{\Gamma(\alpha)}\left(\frac{\beta}{\beta s+1}\right)^{\alpha} \Gamma(\alpha)=\frac{1}{(\beta s+1)^{\alpha}} .
\end{aligned}
$$

Analyzing the Laplace transform of the gamma distribution, we conclude that this distribution law in queuing theory can be used only in special cases with integer values $\alpha \geq 2$.

To apply the method of spectral decomposition of the Lindley integral equation in the last expression, we change the variable $\lambda=1 / \beta$ for the distribution density function of the input flow intervals, $\mu=1 / \beta$ for the distribution density function of the service time and restrict ourselves to the case $\alpha=2$. Thus, in the case of integers $\alpha \geq 2$, the gamma distribution turns into the usual Erlang distribution of order $\alpha$.

For example, when replacing $\lambda=1 / \beta, k=\alpha$, we get the usual Erlang distribution of order $k$ : $f_{\lambda}(t)=\frac{\lambda^{k} t^{k-1} e^{-\lambda t}}{(k-1) !}$. For $k=2$ we get $f_{\lambda}(t)=\lambda^{2} t e^{-\lambda t}$.

This distribution differs from the normalized Erlang distribution considered in [2], where $f_{\lambda}(t)=4 \lambda^{2} t e^{-2 \lambda t}$. The difference between them is that the mathematical expectation of the normalized distribution does not depend on the order of the distribution $k$, therefore, they differ in numerical characteristics [14].

Due to such a difference between the distributions, the QS formed by two flows, in which the time intervals are given by the density functions of the usual second-order Erlang distribution, as a special case of the gamma distribution, we denote $\mathrm{E}_{2} / \mathrm{E}_{2} / 1$ as well as the QS formed by the normalized Erlang distributions. The main (C) Tarasov V. N., 2021

DOI 10.15588/1607-3274-2021-3-5 differences between the normal (derived from the gamma distribution) and normalized $\mathrm{E}_{2}$ Erlang distributions are shown in Tables 1 and 2.

Table 1 - Numerical characteristics of distributions

\begin{tabular}{|c|c|c|c|}
\hline Distribution & $\bar{\tau}_{\lambda}$ & $\overline{\tau_{\lambda}^{2}}$ & $c_{\lambda}^{2}$ \\
\hline Erlangian usual $\mathrm{E}_{2}$ & $2 / \lambda$ & $6 / \lambda^{2}$ & $1 / 2$ \\
\hline Erlangian normalized $\mathrm{E}_{2}$ & $1 / \lambda$ & $3 /\left(2 \lambda^{2}\right)$ & $1 / 2$ \\
\hline
\end{tabular}

Table 2 - Distribution parameter obtained by the method of moments

\begin{tabular}{|c|c|c|}
\hline Distribution & $\begin{array}{c}\text { Density } \\
f_{\lambda}(t)\end{array}$ & Parameter $\lambda$ \\
\hline Erlangian usual $\mathrm{E}_{2}$ & $\lambda^{2} t e^{-\lambda t}$ & $\lambda=2 / \bar{\tau}_{\lambda}$ \\
\hline Erlangian normalized $\mathrm{E}_{2}$ & $4 \lambda^{2} t e^{-2 \lambda t}$ & $\lambda=1 / \bar{\tau}_{\lambda}$ \\
\hline
\end{tabular}

Thus, these distribution laws differ in both parameter and numerical characteristics, except for the coefficient of variation. As we will see below, systems formed by ordinary and normalized Erlang distributions will have different spectral expansions. In this regard, it will be interesting to see the results obtained.

We will assume that the system $E_{2} / E_{2} / 1$ is formed by two flows with the functions of the probability distribution densities:

$$
\begin{gathered}
f_{\lambda}(t)=\lambda^{2} t e^{-\lambda t}, \\
f_{\mu}(t)=\mu^{2} t e^{-\mu t} .
\end{gathered}
$$

Then we will have:

$$
F_{\lambda}^{*}(s)=\left(\frac{\lambda}{\lambda+s}\right)^{2} ; F_{\mu}^{*}(s)=\left(\frac{\mu}{\mu+s}\right)^{2} .
$$

Hence, the spectral expansion $F_{\lambda}^{*}(-s) F_{\mu}^{*}(s)-1=\psi_{+}(s) / \psi_{-}(s)$ of the LIE solution for the system under consideration will take the form:

$$
\begin{aligned}
& \frac{\psi_{+}(s)}{\psi_{-}(s)}=\left(\frac{\lambda}{\lambda-s}\right)^{2}\left(\frac{\mu}{\mu+s}\right)^{2}-1=\frac{\lambda^{2} \mu^{2}-(\lambda-s)^{2}(\mu+s)^{2}}{(\lambda-s)^{2}(\mu+s)^{2}}= \\
& =\frac{-s\left(s^{3}-c_{2} s^{2}-c_{1} s-c_{0}\right)}{(\lambda-s)^{2}(\mu+s)^{2}}
\end{aligned}
$$

where the coefficients of the cubic polynomial collected using symbolic Mathcad operations

$c_{0}=2 \lambda \mu(\mu-\lambda), c_{1}=-\left(\lambda^{2}-4 \lambda \mu+\mu^{2}\right), c_{2}=-2(\mu-\lambda)$.

The cubic polynomial $s^{3}-c_{2} s^{2}-c_{1} s-c_{0}$ of the numerator has two negative roots and one positive one, since in the case of a stable system $\lambda<\mu$ i.e. $(\mu-\lambda)>0$. For convenience, let us denote them by $-s_{1},-s_{2}$ and $s_{3}$. 
Then the zeros of the numerator of the expansion $s=0,-s_{1},-s_{2}, s_{3}$. Double poles of spectral decomposition $s=\lambda, s=-\mu \quad$ (see Fig. 1). Now, considering special conditions [1], we construct functions $\psi_{+}(s)$ and $\psi_{-}(s)$ :

$$
\psi_{+}(s)=\frac{s\left(s+s_{1}\right)\left(s+s_{2}\right)}{(\mu+s)^{2}} ; \quad \psi_{-}(s)=-\frac{(\lambda-s)^{2}}{\left(s-s_{3}\right)} .
$$

Checking the fulfillment of the conditions [1] for these functions is not difficult, this fact is also confirmed by Figure 1.

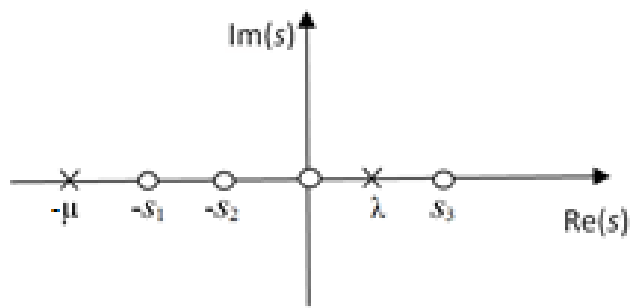

Figure $1-$ Zeros and poles of the function $\psi_{+}(s) / \psi_{-}(s)$ for the $\mathrm{E}_{2} / \mathrm{E}_{2} / 1$ system

When constructing these functions, it is more convenient to mark the zeros and poles of the ratio $\psi_{+}(s) / \psi_{-}(s)$ on the complex $s$ - plane to eliminate errors in constructing the functions $\psi_{+}(s)$ and $\psi_{-}(s)$. In Fig. 1, the poles are marked with crosses, and zeros are marked with circles.

Further, using the method of spectral decomposition, we find the constant $K$ :

$$
K=\lim _{s \rightarrow 0} \frac{\psi_{+}(s)}{s}=\lim _{s \rightarrow 0} \frac{\left(s+s_{1}\right)\left(s+s_{2}\right)}{(\mu+s)^{2}}=\frac{s_{1} s_{2}}{\mu^{2}},
$$

where $s_{1}$ and $s_{2}$ are the absolute values of negative roots $-s_{1},-s_{2}$. The constant $K$ is known to represent the probability that a demand entering the system finds it free.

Now let us build an intermediate function

$$
\Phi_{+}(s)=\frac{K}{\psi_{+}(s)}=\frac{s_{1} s_{2}(s+\mu)^{2}}{\mu^{2} s\left(s+s_{1}\right)\left(s+s_{2}\right)} .
$$

Hence, for the system $E_{2} / E_{2} / 1$, we obtain the function:

$$
W^{*}(s)=s \cdot \Phi_{+}(s)=\frac{s_{1} s_{2}(s+\mu)^{2}}{\mu^{2}\left(s+s_{1}\right)\left(s+s_{2}\right)} .
$$

Comparison with a similar function for the $E_{2} / E_{2} / 1$ system formed by the normalized Erlang distributions from [2] also confirms their difference:

$$
W^{*}(s)=\frac{s_{1} s_{2}(2 \mu+s)^{2}}{4 \mu^{2}\left(s+s_{1}\right)\left(s+s_{2}\right)} .
$$

(C) Tarasov V. N., 2021

DOI 10.15588/1607-3274-2021-3-5
To find the average waiting time, we find the derivative of the function $W^{*}(s)$ with a minus sign at the point $s=0$, for which we use the Mathcad package:

$$
-\left.\frac{d W^{*}(s)}{d(s)}\right|_{s=0}=\frac{s_{1}+s_{2}}{s_{1} s_{2}}-\frac{1}{\mu}=\frac{1}{s_{1}}+\frac{1}{s_{2}}-\frac{1}{\mu} .
$$

Finally, the average waiting time for the $E_{2} / E_{2} / 1$ system

$$
\bar{W}=\frac{1}{s_{1}}+\frac{1}{s_{2}}-\frac{1}{\mu},
$$

where $s_{1}$ and $s_{2}$ how the roots of the cubic equation are expressed through the parameters of distributions (3) and (4).

Next, consider QS, for which the distribution laws of the input flow and service time are given by the density functions shifted to the right:

$$
\begin{aligned}
& f_{\lambda}(t)=\lambda^{2}\left(t-t_{0}\right) e^{-\lambda\left(t-t_{0}\right)}, \\
& f_{\mu}(t)=\mu^{2}\left(t-t_{0}\right) e^{-\mu\left(t-t_{0}\right)} .
\end{aligned}
$$

We denote such a system $\mathrm{E}_{2}^{-} / \mathrm{E}_{2}^{-} / 1$.

To find the average waiting time in the queue for this system, we prove the following statement.

Statement. The spectral decompositions $F_{\lambda}^{*}(-s) F_{\mu}^{*}(s)-1=\psi_{+}(s) / \psi_{-}(s)$ of the LIE solution for systems $E_{2}^{-} / E_{2}^{-} / 1$ and $E_{2} / E_{2} / 1$ completely coincide and have the form (5), i.e. the spectral decomposition is invariant to the operation of the time shift of the density function.

Proof. The Laplace transform of functions (8) and (9), respectively, have the form:

$$
F_{\lambda}^{*}(-s)=\left(\frac{\lambda}{\lambda-s}\right)^{2} e^{t_{0} s} ; F_{\mu}^{*}(s)=\left(\frac{\mu}{\mu+s}\right)^{2} e^{-t_{0} s} .
$$

Then for a $E_{2}^{-} / E_{2}^{-} / 1$ system, the spectral decomposition will be:

$$
\begin{aligned}
& \frac{\psi_{+}(s)}{\psi_{-}(s)}=\left(\frac{\lambda}{\lambda-s}\right)^{2} e^{t_{0} s} \times\left(\frac{\mu}{\mu+s}\right)^{2} e^{-t_{0} s}-1= \\
& =\left(\frac{\lambda}{\lambda-s}\right)^{2}\left(\frac{\mu}{\mu+s}\right)^{2}-1 .
\end{aligned}
$$

Here, exponents with opposite signs of exponential functions are reset to zero, and thus the shift operation in the spectral decomposition is leveled. Thus, the spectral decompositions of the solution of the LIE for the two systems under consideration coincide.

Assertion is proved. 
Corollary. The formula for the average waiting time for a system with shifted distributions will have exactly the same form as for system with ordinary distributions, but with changed parameters $\lambda$ и $\mu$ due to a time shift operation [2-6]. Consequently, the average waiting time for systems with lag actually depends on the magnitude of the shift parameter $t_{0}>0$.

To determine the unknown distribution parameters, we use the Laplace transform of function (8). The average value of the interval between arrivals is given by the first derivative of the Laplace transform with a minus sign at the point $s=0$ :

$$
-\left.\frac{d F_{\lambda}^{*}(s)}{d s}\right|_{s=0}=\left.\left[\frac{2 \lambda^{2} e^{-t_{0} s}}{(\lambda+s)^{3}}+\frac{\lambda^{2} t_{0} e^{-t_{0} s}}{(\lambda+s)^{2}}\right]\right|_{s=0}=2 / \lambda+t_{0} .
$$

From here we get an expression for $\bar{\tau}_{\lambda}$ :

$$
\bar{\tau}_{\lambda}=2 / \lambda+t_{0} .
$$

From the expression

$$
\begin{gathered}
\left.\frac{d^{2} F_{\lambda}^{*}(s)}{d s^{2}}\right|_{s=0}=\frac{6}{\lambda^{2}}+4 \frac{t_{0}}{\lambda}+t_{0}^{2} \text { we find } \\
\overline{\tau_{\lambda}^{2}}=\frac{6}{\lambda^{2}}+4 \frac{t_{0}}{\lambda}+t_{0}^{2}
\end{gathered}
$$

Determine the square of the coefficient of variation

$$
c_{\lambda}^{2}=\frac{\overline{\tau_{\lambda}^{2}}-\left(\overline{\tau_{\lambda}}\right)^{2}}{\left(\overline{\tau_{\lambda}}\right)^{2}}=\frac{2}{\left(2+\lambda t_{0}\right)^{2}} .
$$

From here the value for $c_{\lambda}$ :

$$
c_{\lambda}=\sqrt{2} /\left(2+\lambda t_{0}\right)
$$

Note that for the distribution $E_{2}: \bar{\tau}_{\lambda}=2 / \lambda, c_{\lambda}=1 / \sqrt{2}$.

Comparing the results of the numerical characteristics $\bar{\tau}_{\lambda}, c_{\lambda}$ for the distributions $\mathrm{E}_{2}$ and $\mathrm{E}_{2}^{-}$you can see the difference between them, obtained as a result of the shift of the distribution laws by value $t_{0}>0$. The coefficient of variation $c_{\lambda}$ for the distribution $\mathrm{E}_{2}^{-}$decreases with a shift $\left(1+\lambda t_{0} / 2\right)$ in times compared to the coefficient $c_{\lambda}$ for the distribution $\mathrm{E}_{2}$.

For the service time according to the law $\mathrm{E}_{2}^{-}$, we obtain similar expressions for determining $\mu$ and $c_{\mu}$ :

$$
\bar{\tau}_{\mu}=2 / \mu+t_{0} .
$$

$$
c_{\mu}=\sqrt{2} /\left(2+\mu t_{0}\right) .
$$

By setting the values obtained above as input parameters $\bar{\tau}_{\lambda}, \bar{\tau}_{\mu}, c_{\lambda}, c_{\mu}$ for calculating the $\mathrm{E}_{2}^{-} / \mathrm{E}_{2}^{-} / 1$ system, as well as the shift parameter $t_{0}$ according to expressions (10) - (13), you can calculate the average waiting time using the calculation formula (7). In this case, the ranges of variation of the variation coefficients $c_{\lambda} \in(0,1 / \sqrt{2})$ and $c_{\mu} \in(0,1 / \sqrt{2})$, are determined by relations (11) and (13), respectively, depending on the magnitude of the shift parameter $t_{0}>0$.

Considering that the average waiting time in the $\mathrm{G} / \mathrm{G} / 1$ system is related to the coefficients of variation of the time between the arrivals of customers and the service time by a quadratic dependence, in a system with delay the waiting time will be shorter than in a conventional system, which is illustrated in the next section.

\section{EXPERIMENTS}

Below in Table 3 shows the calculation data for the $E_{2}^{-} / E_{2}^{-} / 1$ system for cases of low, medium and high load $\rho=0.1 ; 0.5 ; 0.9$. For comparison, the right column

\begin{tabular}{|c|c|c|c|c|c|}
\hline \multicolumn{4}{|c|}{ Input parameters } & \multicolumn{2}{|c|}{ Average delay } \\
\hline$\rho$ & $c_{\lambda}$ & $c_{\mu}$ & $t_{0}$ & $\begin{array}{c}\text { For QS } \\
\mathrm{E}_{2}^{-} / \mathrm{E}_{2}^{-} / 1\end{array}$ & $\begin{array}{l}\text { For QS } \\
E_{2} / E_{2} / 1\end{array}$ \\
\hline \multirow{4}{*}{0.1} & 0.643 & 0.071 & 0.9 & 0.000 & \multirow{4}{*}{0.017} \\
\hline & 0.672 & 0.354 & 0.5 & 0.002 & \\
\hline & 0.700 & 0.636 & 0.1 & 0.013 & \\
\hline & 0.706 & 0.700 & 0.01 & 0.016 & \\
\hline \multirow{4}{*}{0.5} & 0.389 & 0.071 & 0.9 & 0.001 & \multirow{4}{*}{0.390} \\
\hline & 0.530 & 0.354 & 0.5 & 0.081 & \\
\hline & 0.672 & 0.636 & 0.1 & 0.309 & \\
\hline & 0.704 & 0.700 & 0.01 & 0.382 & \\
\hline \multirow{4}{*}{0.9} & 0.134 & 0.071 & 0.9 & 0.034 & \multirow{4}{*}{4.359} \\
\hline & 0.389 & 0.354 & 0.5 & 1.057 & \\
\hline & 0.643 & 0.636 & 0.1 & 3.519 & \\
\hline & 0.701 & 0.700 & 0.01 & 4.271 & \\
\hline
\end{tabular}
shows data for a conventional $\mathrm{E}_{2} / \mathrm{E}_{2} / 1$ system. The load factor in this case is determined by the ratio of the average intervals $\rho=\bar{\tau}_{\mu} / \bar{\tau}_{\lambda}$.

The calculations used the normalized service time $\bar{\tau}_{\mu}=1$.

Table 3 - Results of experiments for QS $\mathrm{E}_{2}^{-} / \mathrm{E}_{2}^{-} / 1$ and

$$
\mathrm{E}_{2} / \mathrm{E}_{2} / 1
$$

Despite the large differences between the usual and normalized Erlang distributions shown in Tables 1 and 2, as well as the difference between the Laplace transforms of the waiting time density function, the data in Table 3 completely coincide with the corresponding data for the QS with normalized Erlang distributions $\mathrm{E}_{2} / \mathrm{E}_{2} / 1$ [2]. 
This phenomenon, now after conducting computational experiments, can be explained by the following facts: first, the ordinary and normalized Erlang distributions have the same coefficients of variation, and secondly, the input parameter $\rho=\frac{\bar{\tau}_{\mu}}{\bar{\tau}_{\lambda}}=\frac{2 \lambda}{2 \mu}=\frac{\lambda}{\mu}$ for the ordinary Erlang distribution completely coincides with for the normalized Erlang distribution.

\section{RESULTS}

In this work, spectral expansions of the solution to the Lindley integral equation for the ordinary system and the system with delay are obtained, with the help of which a calculation formula for the average waiting time in the queue for the system $E_{2} / E_{2} / 1$ in closed form is derived.

This calculation formula is also valid for a system with a time delay $E_{2}^{-} / E_{2}^{-} / 1$, considering changes in the numerical characteristics of its shifted distributions. The average waiting time in a system with delay, as expected, is many times less than in a conventional system, and as the value of the shift parameter decreases, it approaches the average waiting time in a conventional system.

The calculation data in Table 3 are in good agreement with the results of the method of two-moment approximation of the processes of arrival and departure of claims [7].

\section{DISCUSSION}

The results of Table 3 confirm the complete adequacy of the constructed mathematical models for the average delay of requests in the queue for a conventional $E_{2} / E_{2} / 1$ system and a system with delay. Table data 3 fully confirm the above assumptions about the average waiting time in a system with delay.

In addition, with a decrease in the shift parameter $t_{0}$, the average queue delay in a system with delay tends to the value of this time in a conventional system, which additionally confirms the adequacy of the constructed mathematical models for both systems under consideration.

The range of variation of the parameters of the system is wider than that of the conventional $E_{2} / E_{2} / 1$ system, therefore, these systems can be successfully applied in the modern theory of teletraffic. The results of the performed experiments confirm the expansion of the ranges of variation of the parameters for the system with delay for $c_{\lambda}$ and $c_{\mu}$ from 0 to $1 / \sqrt{2}$.

Thus, the introduction of distributions shifted to the right from the zero point expands the range of variation of the coefficients of variation of the arrival intervals and service time, thereby expanding the scope of these QSs.

Using the proposed approach, in addition to the average waiting time, it is possible to determine the variance and moments of higher orders of the waiting time.

\section{CONCLUSIONS}

In this work, the problem of deriving a formula for the average delay of requests in the queue for the considered systems is solved.

The scientific novelty of the results is that for the first time the spectral decomposition of the solution of the Lindley integral equation for the considered systems was obtained which are used to derive expression for the average waiting time in the queue for this system in closed form.

These expressions complement and expands the wellknown incomplete formula for the average waiting time in the $\mathrm{G} / \mathrm{G} / 1$ systems with arbitrary laws of input flow distribution and service time.

The practical significance of the work lies in the fact that the obtained results can be successfully applied in the modern theory of teletraffic, where the delays of incoming traffic packets play a primary role. For this, it is necessary to know the numerical characteristics of the incoming traffic intervals and the service time at the level of the first two moments, which does not cause difficulties when using modern traffic analyzers [10].

Prospects for further research are seen in the continuation of the study of systems of type $\mathrm{G} / \mathrm{G} / 1$ with other common input distributions and in expanding and supplementing the formulas for average waiting time.

\section{ACKNOWLEDGEMENTS}

This work was carried out as part of the author's scientific school "Methods and Models for the Research of Computing Systems and Networks", registered at the Russian Academy of Natural Sciences on 31.03.2015 and was supported by the University of PSUTI.

\section{REFERENCES}

1. Kleinrock L. Queueing Systems, Vol. I. Theory. New York, Wiley, 1975, $417 \mathrm{p}$.

2. Tarasov V. N., Bakhareva N. F. Research of queueing systems with shifted erlangian and exponential input distributions, Radio Electronics, Computer Science, Control, 2019, No. 1, pp. 67-76. DOI: 10.15588/1607-3274-2019-1-7

3. Tarasov V. N. The analysis of two queuing systems HE2/M/1 with ordinary and shifted input distributions, Radio Electronics, Computer Science, Control, 2019, No. 2, pp. 71-79. DOI: 10.15588/1607-3274-2019-2-8

4. Tarasov V. N. Queueing systems with delay, Radio Electronics, Computer Science, Control, 2019, No. 3, pp. 55-63. DOI: 10.15588/1607-3274-2019-3-7

5. Tarasov V. N., Bakhareva N. F. Comparative analysis of two queuing systems M/HE2/1 with ordinary and with the shifted input distributions, Radio Electronics, Computer Science, Control, 2019, No. 4, pp. 50-58. DOI: 10.15588/1607-3274-2019-4-5

6. Tarasov V. N. Analysis of H-2/E-2/1 system and her of the analog with shifted input distributions, Radio Electronics, Computer Science, Control, 2020, No. 1, pp. 90-97. DOI: 10.15588/1607-3274-2020-1-10

7. Kruglikov V. K., Tarasov V. N. Analysis and calculation of queuing-networks using the two-dimensional diffusionapproximation, Automation and Remote Control, 1983, No. 8, pp. 1026-1034. 
8. Brannstrom N. A. Queueing Theory analysis of wireless radio systems. Appllied to HS-DSCH. Lulea university of technology, 2004, 79 p.

9. Whitt W. Approximating a point process by a renewal process: two basic methods, Operation Research, 1982, Vol. 30, No. 1, pp. 125-147.

10. Novitzky S., Pender J., Rand R. H., Wesson E. Limiting the oscillations in queues with delayed information through a novel type of delay announcement, Queueing Systems, 2020, Vol. 95, pp. 281-330. DOI: https://doi.org/10.1007/s11134-020-09657-9

11. Novitzky S., Pender J., Rand R. H., Wesson E. Nonlinear Dynamics in Queueing Theory: Determining the Size of Oscillations in Queues with Delay. SIAM J. Appl. Dyn. Syst., 18-1 2019, Vol. 18, No. 1, pp. 279-311. DOI: https://doi.org/10.1137/18M1170637

12. RFC 3393 [IP Packet Delay Variation Metric for IP Performance Metrics (IPPM)] Available at: https://tools.ietf.org/html/rfc3393. (accessed: 26.02.2016).

13. Myskja A. An improved heuristic approximation for the GI/GI/1 queue with bursty arrivals. Teletraffic and datatraffic in a Period of Change. ITC-13. Elsevier Science Publishers, 1991, pp. 683-688.

14. Aliev T. I. Osnovy modelirovaniya diskretnyh system. SPb, SPbGU ITMO, 2009, 363 p.

15. Aras A. K., Chen X. \& Liu Y. Many-server Gaussian limits for overloaded non-Markovian queues with customer abandonment, Queueing Systems, 2018, Vol. 89, No. 1, pp. 81-125. DOI: https://doi.org/10.1007/s11134-018-9575-0

16. Jennings O. B. \& Pender J. Comparisons of ticket and standard queues, Queueing Systems, 2016, Vol. 84, No. 1, pp. 145-202. DOI: https://doi.org/10.1007/s11134-0169493-y

УДК 621.391.1:621.395

Тарасов В. Н. - д-р техн. наук, професор, завідувач кафедри програмного забезпечення та управління в технічних системах Поволзького державного університету телекомунікацій та інформатики, РФ.

\section{МОДЕЛІ ЗАТРИМКИ НА БАЗІ СИСТЕМ З ЗВИЧАЙНИМИ ТА З ЗСУНУТИМИ ГІПЕРЕКСПОНЕНТНИМ ТА ГІПЕРЕРЛАНГІВСЬКИМ ВХІДНИМИ РОЗПОДІЛАМИ}

Актуальність. Для моделювання різних систем передачі даних затребувані системи масового обслуговування G/G/1, це особливо актуально в зв'язку з тим, що для них не існує рішення в кінцевому вигляді в загальному випадку. Розглянуто задачу виведення рішення для середньої затримки в черзі у замкнутій формі для двох систем зі звичайними і $з$ зсунутими ерлангівськимі вхідними розподілами.

Мета роботи. Отримання рішення для основної характеристики системи - середньої затримки вимог в черзі для двох систем масового обслуговування типу G/G/1 зі звичайними і з зсунутими ерлангівськими вхідними розподілами.

Метод. Для вирішення поставленого завдання був використаний класичний метод спектрального розкладання розв'язку інтегрального рівняння Ліндлі. Цей метод дозволяє отримати рішення для середньої затримки для розглянутих систем у замкнутій формі. Для практичного застосування отриманих результатів використаний відомий метод моментів теорії ймовірностей.

Результати. Вперше отримано спектральні розкладання розв'язку інтегрального рівняння Ліндлі для двох систем, за допомогою яких виведені розрахункові формули для середньої затримки в черзі в замкнутій формі.

Висновки. Різниця між звичайним і нормованим розподілом полягає в тому, що у нормованого розподілу математичне сподівання не залежить від порядку розподілу $k$, отже, нормоване і звичайне розподілу Ерланга відрізняються числовими характеристиками. Введення параметра зсуву в часі в закони розподілу вхідного потоку і часу обслуговування для розглянутих систем, перетворює їх в системи запізненням з меншим часом очікування. Це пов'язано 3 тим, що операція зсуву в часі зменшує величину коефіцієнтів варіацій інтервалів між надходженнями вимог і їх часу обслуговування, а як відомо 3 теорії масового обслуговування, середній час очікування вимог пов'язано з цими коефіцієнтами варіацій квадратичною залежністю. Якщо система 3 ерлангівськими вхідними розподілами другого порядку працює тільки при одному точковому значенні коефіцієнтів варіацій інтервалів між надходженнями вимог і їх часу обслуговування, то ця ж система з зсунутими розподілами дозволяє оперувати з інтервальними значеннями коефіцієнтів варіацій, що розширює

(C) Tarasov V. N., 2021

DOI $10.15588 / 1607-3274-2021-3-5$ 
сферу застосування цих систем. Такий підхід дозволяє розрахувати середньої затримки для зазначених систем в математичних пакетах для широкого діапазону зміни параметрів трафіку.

Крім середнього часу очікування, такий підхід дає можливість також визначити моменти вищих порядків часу очікування. 3 огляду на той факт, що варіація затримки пакетів (джиттер) в телекомунікації визначається як дисперсія затримки від його середнього значення, то джиттер можна буде визначити через дисперсію затримки.

КЛЮЧОВІ СЛОВА: звичайний і нормований закони розподілу Ерланга, інтегральне рівняння Ліндлі, метод спектрального розкладання, перетворення Лапласа.

УДК 621.391.1:621.395

\section{СРАВНЕНИЕ ДВУХ ФОРМ ЗАКОНА РАСПРЕДЕЛЕНИЯ ЭРЛАНГА В ТЕОРИИ МАССОВОГО ОБСЛУЖИВАНИЯ}

Тарасов В. Н. - д-р техн. наук, профессор, заведующий кафедрой программного обеспечения и управления в технических системах Поволжского государственного университета телекоммуникаций и информатики, РФ.

\section{АННОТАЦИЯ}

Актуальность. Для моделирования различных систем передачи данных востребованы системы массового обслуживания $\mathrm{G} / \mathrm{G} / 1$, это особо актуально в связи с тем, что для них не существует решения в конечном виде в общем случае. Рассмотрена задача вывода решения для среднего времени ожидания в очереди в замкнутой форме для обычных систем с эрланговскими входными распределениями второго порядка и для этих же систем со сдвинутыми вправо распределениями.

Цель работы. Получение решения для основной характеристики системы - среднего времени ожидания требований в очереди для двух систем массового обслуживания типа $\mathrm{G} / \mathrm{G} / 1$ с обычными и со сдвинутыми эрланговскими входными распределениями.

Метод. Для решения поставленной задачи использован метод спектрального разложения решения интегрального уравнения Линдли, который позволяет получить решение для среднего времени ожидания для рассматриваемых систем в замкнутой форме. Для практического применения полученных результатов использован известный метод моментов теории вероятностей.

Результаты. Впервые получены спектральные разложения решения интегрального уравнения Линдли для систем с обычными и сдвинутыми распределениями Эрланга, с помощью которых выведены расчетные формулы для среднего времени ожидания в очереди для вышеуказанных систем в замкнутой форме.

Выводы. Разница между обычным и нормированным распределением заключается в том, что у нормированного распределения математическое ожидание не зависит от порядка распределения, следовательно, нормированное и обычное распределения Эрланга отличаются числовыми характеристиками. Введение параметра сдвига во времени в законы распределения входного потока и времени обслуживания для рассматриваемых систем, преобразует их в системы запаздыванием с меньшим временем ожидания. Это связано с тем, что операция сдвига во времени уменьшает величину коэффициентов вариаций интервалов между поступлениями требований и их времени обслуживания, а как известно из теории массового обслуживания, среднее время ожидания требований связано с этими коэффициентами вариаций квадратичной зависимостью. Если система с эрланговскими входными распределениями второго порядка работает только при одном точечном значении коэффициентов вариаций интервалов между поступлениями требований и их времени обслуживания, то эта же система со сдвинутыми распределениями позволяет оперировать с интервальными значениями коэффициентов вариаций, что расширяет область применения этих систем. Такой подход позволяет рассчитать среднее время ожидания для указанных систем в математических пакетах для широкого диапазона изменения параметров трафика.

КЛЮЧЕВЫЕ СЛОВА: обычный и нормированный эрланговский законы распределения, интегральное уравнение Линдли, метод спектрального разложения, преобразование Лапласа.

\section{ЛІТЕРАТУРА / ЛИТЕРАТУРА}

1. Kleinrock L. Queueing Systems, Vol. I: Theory / L. Kleinrock. - New York : Wiley, 1975. - 417 p.

2. Tarasov V. N. Research of queueing systems with shifted erlangian and exponential input distributions / V. N. Tarasov, N. F. Bakhareva // Radio Electronics, Computer Science, Control. - 2019. - № 1. - P. 67-76. DOI: $10.15588 / 1607-3274-2019-1-7$

3. Tarasov V. N. The analysis of two queuing systems HE2/M/1 with ordinary and shifted input distributions / V. N. Tarasov // Radio Electronics, Computer Science, Control. - 2019. - № 2. - P. 71-79. DOI: 10.15588/16073274-2019-2-8

4. Tarasov V. N. Queueing systems with delay / V. N. Tarasov // Radio Electronics, Computer Science, Control. - 2019. - № 3. - P. 55-63. DOI: 10.15588/16073274-2019-3-7
5. Tarasov V. N. Comparative analysis of two queuing systems M/HE2/1 with ordinary and with the shifted input distributions / V. N. Tarasov, N. F. Bakhareva // Radio Electronics, Computer Science, Control. - 2019. - № 4. P. 50-58. DOI: 10.15588/1607-3274-2019-4-5

6. Tarasov V. N. Analysis of H-2/E-2/1 system and her of the analog with shifted input distributions / V. N. Tarasov // Radio Electronics, Computer Science, Control. - 2020. № 1. - P. 90-97. DOI: 10.15588/1607-3274-2020-1-10

7. Kruglikov V. K. Analysis and calculation of queuingnetworks using the two-dimensional diffusionapproximation / V. K. Kruglikov, V. N. Tarasov // Automation and Remote Control. - 1983. - № 8. - P. 10261034.

8. Brannstrom N. A Queueing Theory analysis of wireless radio systems / N. Brannstrom. - Appllied to HS-DSCH. Lulea university of technology, 2004. $-79 \mathrm{p}$. 
9. Whitt W. Approximating a point process by a renewal process: two basic methods / W. Whitt // Operation Research. - 1982. - № 1. - P. 125-147.

10. Limiting the oscillations in queues with delayed information through a novel type of delay announcement / [S. Novitzky, J. Pender, R. H. Rand, E. Wesson] // Queueing Systems. 2020. - Vol. 95. - P. 281-330. DOI: https://doi.org/10.1007/s11134-020-09657-9

11. Nonlinear Dynamics in Queueing Theory: Determining the Size of Oscillations in Queues with Delay / [S. Novitzky, J. Pender, R. H. Rand, E. Wesson] // SIAM J. Appl. Dyn. Syst. - 2019. - № 1. - P. 279-311. DOI: https://doi.org/10.1137/18M1170637

12. HTTPS://tools.ietf.org/html/rfc3393. RFC 3393 IP Packet Delay Variation Metric for IP Performance Metrics (IPPM) (accessed: 26.02.2016).

13. Myskja A. An improved heuristic approximation for the GI/GI/1 queue with bursty arrivals / A. Myskja // Teletraffic and datatraffic in a Period of Change, ITC-13. Elsevier Science Publishers. - 1991. - P. 683-688.

14. Aliev T. I. Approximation of Probability Distributions in Queuing Models / T. I. Aliev // Scientific and technical bulletin of information technologies, mechanics and optics. - 2013. - № 2. - P. 88-93.

15. Aras A. K. Many-server Gaussian limits for overloaded non-Markovian queues with customer abandonment / A. K. Aras, X. Chen, Y. Liu // Queueing Systems. 2018. - Vol. 89, № 1. - P. 81-125. DOI: https://doi.org/10.1007/s11134-018-9575-0

16. Jennings O. B. Comparisons of ticket and standard queues O. B. Jennings, J. Pender // Queueing Systems. - 2016. Vol. 84, № 1. - P. 145-202. DOI: https://doi.org/10.1007/s11134-016-9493-y

17. Gromoll H. C. Heavy traffic limit for a tandem queue with identical service times / H. C. Gromoll, B. Terwilliger,
B. Zwart // Queueing Systems. - 2018. - Vol. 89, № 3. P. 213-241. DOI: https://doi.org/10.1007/s11134-0179560-Z

18. Legros B. M/G/1 queue with event-dependent arrival rates / B. Legros // Queueing Systems. - 2018. - Vol. 89, № 3. - P. 269-301. DOI: https://doi.org/10.1007 /s11134-017-9557-7

19. Bazhba M. Queue with heavy-tailed Weibull service times / M. Bazhba, J. Blanchet, C. H. Rhee // Queueing Systems. - 2019. - Vol. 93, № 11. - P. 1-32. DOI: https://doi.org/10.1007/s11134-019-09640-z/

20. Adan I. Special volume on 'Recent Developments in Queueing Theory' of the third ECQT conference / I. Adan, B. D'Auria, O. Kella // Queueing Systems. - 2019. Vol. 93, № $1 . \quad-\quad$ P. $1-190 . \quad$ DOI https://doi.org/10.1007/s11134-019-09630-1

21. Adan I. Special volume on 'Recent Developments in Queueing Theory' of the third ECQT conference: part $2 /$ I. Adan, B. D'Auria, O. Kella // Queueing Systems. 2019. - P. 1-2. DOI: https://doi.org/10.1007/s11134-01909637-8

22. Tibi D. Martingales and buffer overflow for the symmetric shortest queue model / D. Tibi // Queueing Systems. - 2019. - Vol. 93. - P. 153-190. DOI: 10.1007/s11134-019-09628-9

23. Jacobovic R. Asymptotic independence of regenerative processes with a special dependence structure / R. Jacobovic, O. Kella // Queueing Systems. - 2019. Vol. 93. - P. 139-152. DOI: 10.1007/s11134-019-096061

24. Wang L. Fluid and diffusion models for a system of taxis and customers with delayed matching / L. Wang, V. Kulkarni // Queueing Systems. - 2020. - Vol. 96. P. 101-131. DOI: 10.1007/s11134-020-09659-7 